\title{
Analysis of the use of social media in Higher Education Institutions (HEls) using the Technology Acceptance Model
}

Open Access

\author{
Duvince Zhalimar Dumpit ${ }^{1 *}$ and Cheryl Joy Fernandez ${ }^{2}$
}

\author{
* Correspondence: \\ djdumpit@up.edu.ph \\ 'Department of Accounting, \\ College of Management University \\ of the Philippines Visayas, lloilo City, \\ Philippines 5000 \\ Full list of author information is \\ available at the end of the article
}

\begin{abstract}
The purpose of this paper is to extend the understanding of the drivers of social media in higher education institutions (HEls) in an emerging economy. This research adopts the Technology Acceptance Model but included subjective norm, perceived playfulness, Internet reliability and speed as additional constructs. With these inclusions, the model is appropriate and relevant in explaining users' adoption and usage behavior of social media. Data from 500 students from public and private HEls in the Philippines were collected and analyzed. We used a combination of statistical analyses such as the Principal Component Analysis (PCA) and Structural Equation Modeling (SEM) in analysing the complex relationships between determinants of these technologies. The research demonstrated that perceived usefulness, perceived ease of use, subjective norm, and perceived playfulness (happiness) are robust predictors of usage behavior of students. However, Internet reliability and speed were only significant in (some) public HEls. This evidence may be explained by the fact that information and communications technology (ICT) infrastructure in public HEls is not a priority or underinvested in developing countries. On the other hand, the analysis between public and private HEls undertaken here extends our understanding towards the different behaviors of users. The findings, though preliminary, suggest that private HEls should initiate or continue the use of social media in classrooms, because intention to use translate to actual use of these tools. Public institutions, however, should improve Internet reliability and speed and should reassess their use of social media in order to fully take advantage of the benefits of ICT.
\end{abstract}

Keywords: Technology Acceptance Model, TAM, Social media, YouTube, Higher education institution/university, Philippines, Internet speed, Internet reliability

\section{Introduction}

Information and communications technology (ICT) and education

In today's digital economy, success in businesses is attributed to the effective use of information and communications technology (ICT). Higher Education Institutions (HEIs) are not exempted from these rapidly changing technological advancements and hence, cannot afford to lag behind these developments as these can provide valuable insights to the academic community. For instance, students of today have become technologically savvy and pro-active users of ICTs. They are seen as 'active producers of knowledge' as they become responsible for their learning (McLoughlin \& Lee, 2008). Thus, HEIs, especially educators, need to plan to address uncertainties by discovering/

(c) The Author(s). 2017 Open Access This article is distributed under the terms of the Creative Commons Attribution 4.0 International License (http://creativecommons.org/licenses/by/4.0/), which permits unrestricted use, distribution, and reproduction in any medium, provided you give appropriate credit to the original author(s) and the source, provide a link to the Creative Commons license, and indicate if changes were made. 
adapting new ways and processes to enhance student learning, performance, and satisfaction through the use of ICT.

The image of the future that Teilhard De Chardin (1955), a French philosopher, envisaged, which he called 'Future Earth', included the overwhelming importance of ICTs in transforming communities. De Chardin described the Future Earth as a 'noosphere' (Greek word 'nous' = mind and 'sphaira' $=$ sphere), which encompasses interrelated technologies and consciousness (Levinson, 2011; Peters \& Heraud, 2015). He envisioned the role of technology in engendering a global consciousness, manifested for example, in social media in today's businesses. The Internet and social media also facilitate social production (Peters \& Reveley, 2015), transform users as consumers and/or producers, and bridge the real and virtual worlds (Levinson, 2011). Together, these arguments strengthen the significance of social media in today's contemporary world.

Social media is considered as a one of the game-changers in learning and teaching (Healy, 2015). It is defined by Kietzmann, Hermkens, McCarthy, and Silvestre (2011, p.241) as one that 'employ mobile and web-based technologies to create highly interactive platforms via which individuals and communities share, co-create, discuss, and modify user-generated content.' Generally, it follows the concept of Web 2.0 and consists two key elements: (1) media research (social presence, media richness) and (2) social processes (self-presentation, self-disclosure) (Kaplan \& Haenlein, 2010). Examples of social media are blogs (e.g. WordPress), content communities (e.g. YouTube), social networking sites (e.g. Facebook, LinkedIn), collaborative projects (e.g. Wikipedia), and virtual social worlds (e.g. Second Life) (Balakrishnan \& Gan, 2016; Kaplan \& Haenlein, 2010).

The overwhelming popularity of social media has led to a proliferation of studies that examined its role in higher education. These include analysis of social media usage for learning in relation to students' learning styles (Balakrishnan \& Gan, 2016); relationship between personal, teaching, and professional purposes of use of social media by higher education scholars (Manca \& Ranieri, 2016); learner-generated content and its effects on learning outcomes and satisfaction (Orús et al., 2016); impact of online social networks on academic performance (Paul, Baker, \& Cochran, 2012); and success factors of social networking sites (Schlenkrich \& Sewry, 2012). In his essay 'Social Media in Higher Education, Selwyn, (2012) discussed the educational implications of social media in terms of new types of learners, learning, and higher education provision. He argued that although there are debates on the actual use of social media for learning and knowledge generation, educators are challenged continually to find ways on how to effectively utilize social media in higher education settings.

Findings of previous studies (Balakrishnan \& Gan, 2016; Schlenkrich \& Sewry, 2012; Sobaih, Moustafa, Ghandforoush, \& Khan, 2016) revealed that social media has a great potential for improving learning experience through active interaction and collaboration. However, there are two major gaps that need to be further investigated. First, users' (e.g. students) behavioral intention to use social media is unclear. Second, to the best of our knowledge, few studies have been conducted on social media and its acceptance/rejection in emerging countries such as the Philippines. The issue has grown importance in the light of the recent changes in the business environment (e.g. competitiveness) and advancement in technology in these emerging economies. For example, the Philippines has 48 million active social media users with a social media 
penetration of 47\% in 2016 (Kemp, 2016). Therefore, to ensure successful adoption of social media, it can be argued that there is a need to investigate what drives users to accept or reject the use of social media particularly in these economies.

The central focus of this study, therefore, is to develop an understanding of the factors and causal relationships that influence the acceptance and behavioral intention to use social media. It aims to contribute useful insights on how HEIs can fully maximize the use of social media. Since social media is Internet-based, this study proposed the Technology Acceptance Model (TAM) as a theoretical framework. We discuss this framework below.

\section{Technology Acceptance Model (TAM)}

A considerable amount of literature has been published on user technology acceptance and TAM is one of the most frameworks adopted because of its robustness, simplicity, and applicability in explaining and predicting the attributes that affect user's adoption behavior towards new technologies (Lu, Yu, Liu, \& Yao, 2003; Marangunić \& Granić, 2015; Rauniar, Rawski, Yang, \& Johnson, 2014; Venkatesh \& Davis, 2000).

Davis (1986) developed the TAM (Fig. 1), which is based on the Theory of Reasoned Action (TRA), to understand the causal relationships among users' internal beliefs, attitudes, and intentions as well as to predict and explain acceptance of computer technology (Davis et al., 1989). This model posits that the user's actual usage behavior (actual use or AU) is directly affected by behavioral intention (intention to use or IU). In turn, behavioral intention is determined by both the user's attitude and its perception of usefulness. The user's attitude is considered to be significantly influenced by two key beliefs, perceived usefulness (PU) and perceived ease of use (PEOU), and that these beliefs act as mediators between external variables (e.g. design features, prior usage and experience, computer self-efficacy, and confidence in technology) and intention to use. Furthermore, TAM theorizes that PEOU indirectly affects IU through PU (Davis et al., 1989; Venkatesh \& Davis, 2000).

The application of TAM is diverse: from wireless Internet (Lu et al., 2003) and multimedia-on-demand (Liao, Tsou, \& Shu, 2008) to collaborative technologies (Cheung \& Vogel, 2013). Large volumes of these studies modified Davis' TAM (1986) to improve its (predictive) validity and applicability to various technologies. For instance, Davis et al. (1989) showed that the attitude construct does not significantly mediate in the belief-intention relationships. In 2000, Venkatesh and Davis (2000)

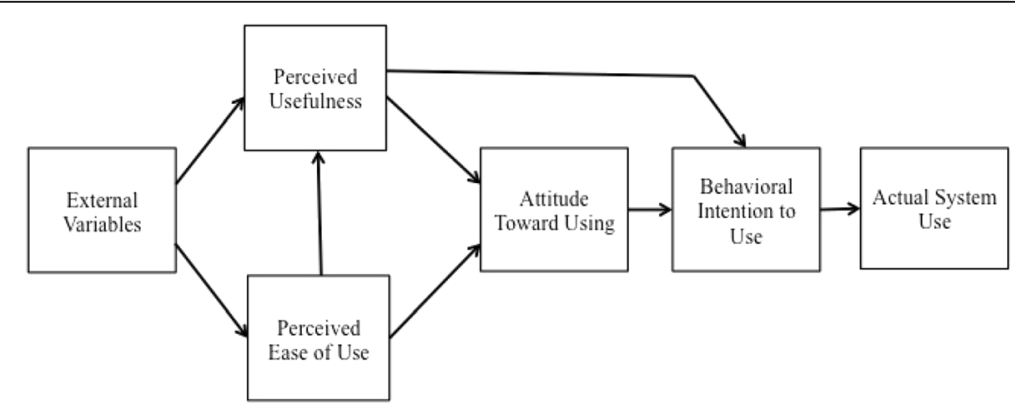

Fig. 1 Technology Acceptance Model (TAM), redrawn from Davis, Bagozzi, and Warshaw (1989, p. 985) 
proposed an extension for TAM (called TAM2), which includes the theoretical constructs of social influence and cognitive instrumental processes. They found that these additional constructs directly affect adoption and usage of "information technology" (IT) in the workplace. Meanwhile, Marangunić and Granić (2015) analyzed 85 scientific publications on TAM from 1986 to 2013 and concluded that studies have continually identified new constructs that play major roles in influencing the core variables (PU and PEOU) of TAM.

Since TAM was originally created to explain computer usage behavior, some researchers argue that factors such as perceived playfulness, perceived critical mass, and social trust should be included to effectively explain the unique characteristics of new technologies such as social networking sites (SNS) (Ernst, Pfeiffer, \& RothLauf, 2013; Oum \& Han, 2011; Rauniar et al., 2014; Sledgianowski \& Kulviwat, 2009). This study recognizes recent developments and therefore, together with the constructs perceived usefulness (PU) and perceived ease of use (PEOU), we added constructs: subjective norm (SN), perceived playfulness (PP), and quality of Internet connection which is comprised of Internet reliability and speed. This is to improve the ability of the model to predict student's adoption and usage behavior of social media.

The remaining part of the paper proceeds as follows: relevant literatures on the research model are described in "The inter-relationships of determinants of TAM" section, then followed by the research methodology in section "Methodology". The results of the analyses are presented in section "Results", and conclusions are described in the final section.

\section{The inter-relationships of determinants of TAM}

Using insights from related studies, we conceptualized a modified framework of TAM for social media (Fig. 2). The research model used original constructs of TAM: perceived usefulness, perceived ease of use, intention to use, and actual use. Additional constructs were included to the model: subjective norm, perceived playfulness, and quality of Internet connection, which is comprised of Internet reliability and speed. A

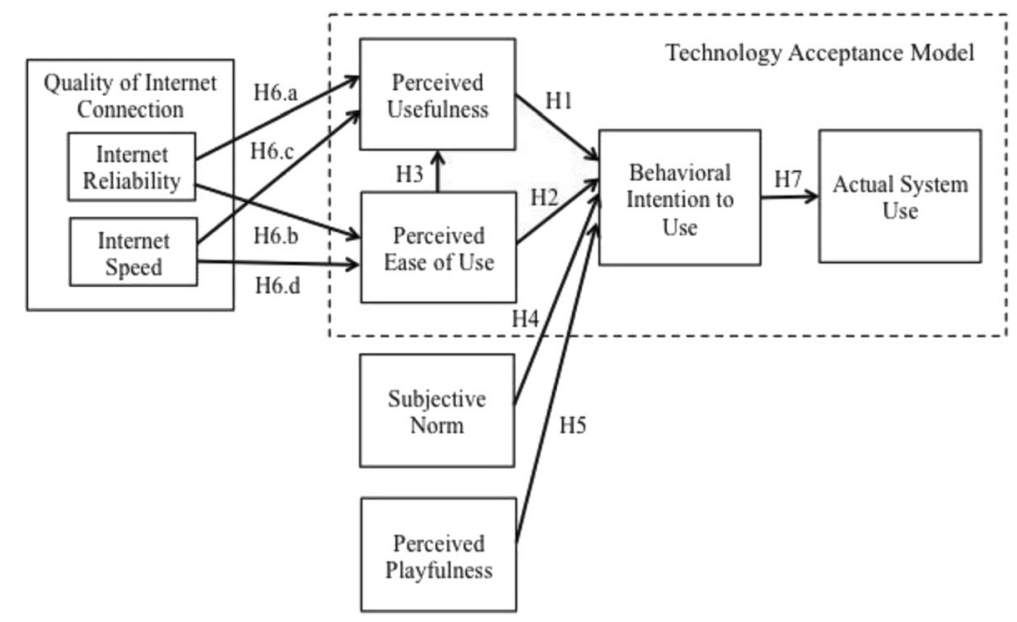

Fig. 2 Hypothesized TAM 
detailed discussion of the underlying hypotheses and the corresponding literature supporting the model is specified below.

Perceived usefulness (PU) and perceived ease of use (PEOU) are fundamental predictors of the adoption and use of technology (Davis, 1989). Davis defined PU as 'the degree to which a person believes that using a particular system would enhance his or her job performance' (1989, p. 320). Whereas, PEOU means 'the degree to which a person believes that using a particular system would be free of effort' (1989, p. 320). These relationships are robust across various types of technologies: m-learning (Althunibat, 2015), Internet-based learning systems (Saadé \& Bahli, 2005), and healthcare information systems (Pai \& Huang, 2011).

In-depth and comprehensive studies of Davis (1989) and Davis et al. (1989) revealed that PU is a stronger driver of usage intention compared to PEOU. A system has favorable PU when it improves the performance of the user. While PEOU becomes less significant as the user becomes more adept at using the system. Interestingly, in social media applications, PU is seen as an inconsistent determinant of intention to use. This may be attributed to the nature/type of the information system (IS) being studied, that is, either hedonic or utilitarian (Ernst et al., 2013; Moqbel, 2012; Sledgianowski \& Kulviwat, 2009). Hedonic IS (such as social media) promotes communication and entertainment to users while, users adopt utilitarian IS (such as online banking) for more efficient processes and other practical application.

TAM also hypothesized that there is a positive correlation between PEOU and PU (Venkatesh \& Davis, 2000). In other words, the less complicated a user performs social media-related activities, the more likely he/she will consider social media sites to be useful. In studies relating to SNS, several authors (Alarcón-Del-Amo, Lorenzo-Romero, \& Gómez-Borja, 2012; Pinho \& Soares, 2011; Rauniar et al., 2014) found that PEOU significantly determine PU, however, this view was not supported in a study of hedonic and utilitarian motivations of SNS adoption in Germany (Ernst et al., 2013). Overall, there seems to be some evidences that PU and PEOU are important in explaining adoption and usage behavior (Alarcón-Del-Amo et al., 2012; Choi \& Chung, 2012; Rauniar et al., 2014; Sledgianowski \& Kulviwat, 2009). Therefore, we hypothesize the following:

Hypothesis 1: High rating of perceived usefulness leads to high intention to use.

Hypothesis 2: High rating of perceived ease of use leads to high intention to use.

Hypothesis 3: High rating of perceived ease of use leads to high perceived usefulness.

Although, not originally a component of Davis (1989) TAM, subjective norm (SN) is seen as a major factor of behavioral intention (Choi \& Chung, 2012; Venkatesh \& Davis, 2000). Sledgianowski and Kulviwat (2009) point out that SN explains the influence of society (e.g. peers, significant others) on the way an individual behaves. Inclusion of SN, according to Arpaci (2016), 'may capture unique variance in attitudes and intentions (p.155).' Analyzing 51 studies, Schepers and Wetzels (2007) explained the critical role of SN to IU and found out that SN has more influence on IU in studies in Western culture. The positive relationship between SN and IU was also evident in the acceptance of airline business-to-customer (B2C) eCommerce websites (AB2CEWS) (Kim, Kim, \& Shin, 2009). The authors proposed that airline companies should developed strategies focused on referents (e.g., family and friends) because a customer's purchasing behavior is influenced by the opinions of those people. Together, these studies 
provide a social dimension to the TAM framework, where $\mathrm{SN}$ is seen as a determinant of intention to use. Therefore, we hypothesize that:

Hypothesis 4: High influence from family and other important people leads to high intention to use.

More recent attention has focused on perceived playfulness (PP, also called perceived enjoyment) as a determinant of usage behavior. It is defined as a degree to which a current or potential user believes that the social network site will bring him/her a sense of enjoyment and pleasure (Sledgianowski \& Kulviwat, 2009). In hedonic information technologies, such as SNS, PP is consistently described as primary/strong indicator of intention to use (Ernst et al., 2013; Moqbel, 2012; Pillai \& Mukherjee, 2011; Sledgianowski \& Kulviwat, 2009). Using cases of SNS, Sledgianowski and Kulviwat (2009) and Moqbel (2012) provide evidence that PP affects IU more as compared to PU and PEOU. In a similar vein, Oum and Han (2011) suggest that service providers should continuously provide users a delightful experience while using their websites because use of user-created content services is significantly influenced by perceived playfulness.

Perceived playfulness in utilitarian technologies was also examined but results were mixed. Studies on technologies such as 3G mobile services (Suki \& Suki, 2011) and blended learning systems (Padilla-Meléndez, Del Aguila-Obra, \& Garrido-Moreno, 2013) revealed that PP is not a direct determinant of IU while on online banking (Pikkarainen, Pikkarainen, Karjaluoto, \& Pahnila, 2004) findings showed otherwise. Together, these studies outline the importance of PP to intention to use the technology, more so in social media sharing sites. Therefore, we hypothesize that:

Hypothesis 5: High rating of perceived playfulness leads to high intention to use.

Without a stable Internet connection, a user will have difficulty accessing online technologies. However, research on the roles of Internet reliability and speed in TAM is scarce. In instances that these two are studied, results are mixed. Al-Somali, Gholami, and Clegg (2009) found that the quality of Internet connection is directly correlated with PEOU of online banking. Fonchamnyo (2013) also attempted to include a proxy for quality of Internet connection, but found it to be incognizant. Similar results have been found in an examination of online banking in Finland (Pikkarainen et al., 2004). However, what is not clear is the impact of speed and reliability of Internet connection to other technologies, such as social media sites. Therefore, we hypothesize the following:

\footnotetext{
Hypothesis 6: High quality of Internet connection leads to high rating of perceived usefulness and perceived ease of use.

H6.a: Favorable Internet reliability leads to high rating of perceived usefulness.

H6.b: Favorable Internet reliability leads to high rating of perceived ease of use.

H6.c: Fast Internet speed leads to high rating of perceived usefulness.

H6.d: Fast Internet speed leads to high rating of perceived ease of use.
}

Behavioral intention to use (IU) is a key determinant of usage behavior (AU), as shown in TRA and TAM (Davis et al., 1989). In general technology use, IU is positively 
correlated with actual use of technology (Ducey \& Coovert, 2016; Lu et al., 2003; Pinho \& Soares, 2011). Turner, Kitchenham, Brereton, Charters, and Budgen (2010) analyzed 79 empirical studies and found out that behavioral intention is a significant determinant of actual usage compared to other TAM variables. Higher usage rate for social media platforms such as Facebook can also be explained by high intention of use (Rauniar et al., 2014). This relationship is also affirmed in other studies on SNSs by that of Sledgianowski and Kulviwat (2009) and Alarcón-Del-Amo et al. (2012). Collectively, these studies give credit to the application of TAM to social media sites. Therefore, we hypothesize that:

Hypothesis 7: High intention to use leads to actual usage.

\section{Methodology}

\section{Higher education institutions and use of social media}

As mentioned in "The inter-relationships of determinants of TAM" section, we wanted to determine factors that affect students' social media usage behavior. Given this, we targeted four higher education institutions in the Philippines - two of which are privately-owned, while the other two are government-owned. Universities in the city of Iloilo are interesting case study areas as the city is considered an educational hub in the Central Philippines. Iloilo is home to more than 100 educational institutions both public and private, 10 of which are major universities (De Rivera, 2016). Furthermore, today's students are considered as 'native speakers of the digital language of computers, video games and the Internet' (Prensky, Digital natives, digital immigrants part 1, 2001, p.1).

YouTube is the focus of our investigation. As cited in the study of Everson, Gundlach, and Miller (2013), it has been used to facilitate learning in various courses such as cultural studies, health education, secondary education, communication ethics, and chemistry. Likewise, online videos in YouTube are one of the most common Internet-based tools used in lectures, assignments, and class presentations (Moran, Seaman, \& TintiKane, 2011).

\section{Questionnaire development and data collection}

As in most TAM studies, information about intention to use and actual use was required, therefore we opted to gather information from users through questionnaire. We took broad steps to formulate the final questionnaire. Studies related to TAM were also reviewed in order to gain insights about various factors that may affect actual use. Most of our review relates to studies that used TAM as well as those relating to consumer behavior (discussed in "The inter-relationships of determinants of TAM" section). Pretesting of questionnaires was conducted through cognitive mapping. In here, we present words (e.g. happy, contented, satisfied, and glad) to student and asked to group words that they think 'go together.' They were also asked to explain their groupings. Thus, we were able to determine appropriate wordings for the final questionnaire. Ten students participated in this cognitive mapping exercise.

Given these, the questionnaire was designed with the following sections: 
1) Information about the research - this section introduces the student to the research, highlighting its aim as well as the confidentiality of the information given. In here, we also presented instructions in answering the questionnaire.

2) Socio-demographic characteristics of students and information relating to their Internet reliability and speed in their respective universities.

3) Statements relating to perceived usefulness, perceived ease of use, perceived playfulness, subjective norm, intention to use, and actual use.

The statements presented in Table 1 were used to explain technology acceptance of students. The third column shows the respective studies which the statements were adapted from.

Written consents from the administrators of four universities were sought before the survey. After this, self-administered questionnaires were distributed by enumerators to enrolled students from Business Departments/Colleges for Academic Year (AY) 20132014 ( $1^{\text {st }}$ Semester). Since the distribution of enrolled students vary significantly between the four universities, we used proportionate sampling (Table 2). A total of 500 respondents were surveyed from July to December 2013. Respondents were recruited purposively, where they spend around 15 to $20 \mathrm{~min}$ in answering the questionnaire.

\section{Results}

\section{Data analysis and preliminary results}

Given the data collected, we ran a series of statistical tests to determine the factors affecting actual use. There were three statements relating to 'perceived playfulness (PP),' 'perceived usefulness (PU),' 'perceived ease of use (PEOU),' 'subjective norm (SN),' and, 'intention to use (IU). We examined whether responses are statistically correlated and whether outcomes may be combined into fewer variables. In order to do this, we ran Principal Component Analysis (PCA) (Jolliffe, 2002) to the three statements for each construct in order to determine possible clustering of responses. In Table 3, there are clear results that most statements may be combined: PEOU, SN and IU with 57, 59, and $66 \%$ of the total variation, respectively; while statements relating to PP $(80 \%)$ and PU (81\%) can be segregated into two factors. For usefulness, responses to statements 'Using the site improves my ability to express myself' and 'Using the site makes me more productive' are combined as the first factor (renamed as 'self-expression and productivity' or PU1). Responses to the statement 'Overall, the site is not very useful to me' (renamed 'overall usefulness' or PU2) are different from these two (factor 2) and will be use separately in the final model. On the other hand, for playfulness, the first factor (or grouping) consists of responses for the statements, 'Using the site is not a good way to spend my leisure time' and 'Using the site does not stimulate my interests' (renamed, 'leisure and interest' or PP1); while the second factor consists of answers to 'Using the site makes me happy' (renamed, 'happiness' or PP2).

After finding and merging statistically associated statements, we ran a structural equation modeling (SEM) using STATA to control for interrelationships between explanatory variables. Most TAM analyses were carried out using SEM to measure the causal relationships between constructs (Arpaci, 2016; Moqbel, 2012; Oum \& Han, 2011; Pinho \& Soares, 2011; Rauniar et al., 2014). 
Table 1 Constructs used in the model

\begin{tabular}{|c|c|c|}
\hline Construct & Statement & Reference \\
\hline \multicolumn{3}{|c|}{ Perceived usefulness } \\
\hline PU1 & $\begin{array}{l}\text { 1) Using the site improves my } \\
\text { ability to express myself. }\end{array}$ & Lane and Coleman (2012) \\
\hline PU2 & $\begin{array}{l}\text { 2) Using the site makes me more } \\
\text { productive in school. }\end{array}$ & Sledgianowski and Kulviwat (2009 \\
\hline PU3 & $\begin{array}{l}\text { 3) Overall, the site is not very } \\
\text { useful to me. }\end{array}$ & Alarcón-Del-Amo et al. (2012) \\
\hline \multicolumn{3}{|c|}{ Perceived Ease of Use } \\
\hline PEOU1 & $\begin{array}{l}\text { 4) Using the site is unclear } \\
\text { and not understandable. }\end{array}$ & Alarcón-Del-Amo et al. (2012) \\
\hline PEOU2 & $\begin{array}{l}\text { 5) I had a hard time learning } \\
\text { how to use the site. }\end{array}$ & Alarcón-Del-Amo et al. (2012) \\
\hline PEOU3 & 6) Overall, the site is easy to use. & Alarcón-Del-Amo et al. (2012) \\
\hline \multicolumn{3}{|c|}{ Subjective Norm } \\
\hline SN1 & $\begin{array}{l}\text { 7) My teachers think I should } \\
\text { use the site. }\end{array}$ & Sledgianowski and Kulviwat (2009 \\
\hline SN2 & $\begin{array}{l}\text { 8) My classmates, whose opinions } \\
\text { I value, recommend the site. }\end{array}$ & Sledgianowski and Kulviwat (2009 \\
\hline SN3 & $\begin{array}{l}\text { 9) Other people I look up to expect } \\
\text { me to use the site. }\end{array}$ & Sledgianowski and Kulviwat (2009) \\
\hline \multicolumn{3}{|c|}{ Perceived Playfulness } \\
\hline PP1 & 10) Using the site makes me happy. & Sledgianowski and Kulviwat (2009) \\
\hline PP2 & $\begin{array}{l}\text { 11) Using the site is not a good way } \\
\text { to spend my leisure time. }\end{array}$ & Liao et al. (2008) \\
\hline PP3 & $\begin{array}{l}\text { 12) Using the site does not stimulate } \\
\text { my interests. }\end{array}$ & Sledgianowski and Kulviwat (2009 \\
\hline \multicolumn{3}{|c|}{ Intention to Use } \\
\hline IU1 & $\begin{array}{l}\text { 13) I intend to begin or continue } \\
\text { using the site. }\end{array}$ & Alarcón-Del-Amo et al. (2012) \\
\hline IU2 & $\begin{array}{l}\text { 14) I will recommend the use of this } \\
\text { site to others. }\end{array}$ & Alarcón-Del-Amo et al. (2012) \\
\hline IU3 & $\begin{array}{l}\text { 15) I intend to use the site in } \\
\text { the future. }\end{array}$ & Liao et al. (2008) \\
\hline \multicolumn{3}{|c|}{ Actual Usage } \\
\hline $\mathrm{AU} 1$ & $\begin{array}{l}\text { 16) On the average, how many } \\
\text { hours per day do you use }\end{array}$ & Sledgianowski and Kulviwat (2009) \\
\hline
\end{tabular}

Table 2 Distribution of sample

\begin{tabular}{|c|c|c|c|c|}
\hline \multirow{2}{*}{$\begin{array}{l}\text { Higher-education } \\
\text { institutions } \\
\text { Private HEI } 1\end{array}$} & \multirow{2}{*}{$\begin{array}{l}\text { Total no. of enrollees } \\
\left(1^{\text {st }} \text { Semester, }\right. \\
\text { AY 2013-2014) } \\
2720\end{array}$} & \multicolumn{2}{|c|}{$\begin{array}{l}\text { No. of Student } \\
\text { Respondents }\end{array}$} & \multirow{2}{*}{$\begin{array}{l}\text { Survey dates } \\
\text { (self-administered } \\
\text { questionnaire) } \\
\text { August to December } 2013\end{array}$} \\
\hline & & 189 & $38 \%$ & \\
\hline Private HEI 2 & 2434 & 170 & $34 \%$ & August to December 2013 \\
\hline Public HEl 1 & 893 & 62 & $12 \%$ & July 2013 \\
\hline Public HEI 2 & 1134 & 79 & $16 \%$ & August to September 2013 \\
\hline Total & 7181 & 500 & $100 \%$ & \\
\hline
\end{tabular}


Table 3 Factor loadings and eigenvalue for various principal component analyses of statements

\begin{tabular}{|c|c|c|}
\hline Statements & Factor 1 & Factor 2 \\
\hline Perceived usefulness & $\begin{array}{l}\text { Eigenvalue: } 1.47 \\
\text { Variance explained } \\
\text { (cumulative \%): } 49 \%\end{array}$ & $\begin{array}{l}\text { Eigenvalue: } 0.95 \\
\text { Variance explained } \\
\text { (cumulative \%): } 81 \%\end{array}$ \\
\hline $\begin{array}{l}\text { Using the site improves my ability to express } \\
\text { myself. }\end{array}$ & 0.64 & - \\
\hline Using the site makes me more productive. & 0.68 & - \\
\hline Overall, the site is not very useful to me. ${ }^{a}$ & - & 0.92 \\
\hline Perceived ease of use & $\begin{array}{l}\text { Eigenvalue: } 1.72 \\
\text { Variance explained } \\
\text { (cumulative \%): 57\% }\end{array}$ & \\
\hline $\begin{array}{l}\text { Using the site is unclear and not } \\
\text { understandable. }\end{array}$ & 0.57 & - \\
\hline $\begin{array}{l}\text { I had a hard time learning how to use the } \\
\text { site. }^{\text {a }}\end{array}$ & 0.61 & - \\
\hline Overall, the site is easy to use. & 0.55 & - \\
\hline Subjective norm & $\begin{array}{l}\text { Eigenvalue: } 1.76 \\
\text { Variance explained } \\
\text { (cumulative \%): } 59 \%\end{array}$ & \\
\hline My teachers think I should use the site. & 0.58 & - \\
\hline $\begin{array}{l}\text { My classmates, whose opinions I value, } \\
\text { recommend the site. }\end{array}$ & 0.57 & - \\
\hline $\begin{array}{l}\text { Other people I look up to expect me to use } \\
\text { the site. }\end{array}$ & 0.58 & - \\
\hline Perceived playfulness & $\begin{array}{l}\text { Eigenvalue: } 1.56 \\
\text { Variance explained } \\
\text { (cumulative \%): } 52 \%\end{array}$ & $\begin{array}{l}\text { Eigenvalue: } 0.83 \\
\text { Variance explained } \\
\text { (cumulative \%): } 80 \%\end{array}$ \\
\hline Using the site makes me happy. & - & 0.83 \\
\hline $\begin{array}{l}\text { Using the site is not a good way to spend my } \\
\text { leisure time. }\end{array}$ & 0.61 & - \\
\hline $\begin{array}{l}\text { Using the site does not stimulate my } \\
\text { interests. }{ }^{a}\end{array}$ & 0.62 & - \\
\hline Intention to use & $\begin{array}{l}\text { Eigenvalue: } 1.97 \\
\text { Variance explained } \\
\text { (cumulative \%): } 66 \%\end{array}$ & \\
\hline I intend to begin or continue using the site. & 0.58 & - \\
\hline I will recommend the use of this site to others. & 0.58 & - \\
\hline I intend to use the site in the future. & 0.57 & - \\
\hline
\end{tabular}

astatement inversely recoded for PCA

\section{Determinants of actual use of social media sites}

In "The inter-relationships of determinants of TAM" section, we described 7 major hypotheses. Table 4 presents the significant relationships between the hypothesized factors, based on various structural equations models (models 1 to 5). The first model is the general model and uses responses from all students from both private and public HEIs. Models 2 to 5, on the other hand, are disaggregated models for sampled HEIs.

In model 1, findings show that perceived self-expression and productivity (PU1) and overall usefulness (PU2) are major determinants of usage behavior. This result is in agreement with the findings of Schlenkrich and Sewry (2012), which showed that usability is a primary factor that determines successful usage of SNS in higher educational institutions. One unanticipated finding was that students' intention to use social media sites from one public university (model 4) was not driven by one's perceived self- 
Table 4 Determinants of social media use in various higher education institutions (HEls)

\begin{tabular}{|c|c|c|c|c|c|c|}
\hline & Path & $\begin{array}{l}\text { (1) } \\
\text { All HEls }\end{array}$ & $\begin{array}{l}(2) \\
\text { Private } \\
\text { HEI } 1\end{array}$ & $\begin{array}{l}\text { (3) } \\
\text { Private } \\
\text { HEI } 2\end{array}$ & $\begin{array}{l}(4) \\
\text { Public } \\
\text { HEI } 1\end{array}$ & $\begin{array}{l}(5) \\
\text { Public } \\
\text { HEl } 2\end{array}$ \\
\hline \multirow[t]{2}{*}{$\mathrm{H} 1$} & Self-expression and productivity (PU1) $\rightarrow I U$ & $\begin{array}{l}0.19^{* * *} \\
(0.00)\end{array}$ & $\begin{array}{l}0.11^{* *} \\
(0.07)\end{array}$ & $\begin{array}{l}0.31^{* * *} \\
(0.00)\end{array}$ & $\begin{array}{l}0.13 \\
(0.15)\end{array}$ & $\begin{array}{l}0.31^{* * *} \\
(0.00)\end{array}$ \\
\hline & $\begin{array}{l}\text { Overall usefulness } \\
\text { (PU2) } \rightarrow I U\end{array}$ & $\begin{array}{l}0.09^{* * *} \\
(0.00)\end{array}$ & $\begin{array}{l}0.12^{* *} \\
(0.02)\end{array}$ & $\begin{array}{l}0.10^{* * *} \\
(0.00)\end{array}$ & $\begin{array}{l}0.15^{* *} \\
(0.04)\end{array}$ & $\begin{array}{l}-0.04 \\
(0.51)\end{array}$ \\
\hline $\mathrm{H} 2$ & $\mathrm{PEOU} \rightarrow \mathrm{IU}$ & $\begin{array}{l}0.30^{* * *} \\
(0.00)\end{array}$ & $\begin{array}{l}0.34^{* * *} \\
(0.00)\end{array}$ & $\begin{array}{l}0.21^{* * *} \\
(0.00)\end{array}$ & $\begin{array}{l}0.32^{* *} \\
(0.01)\end{array}$ & $\begin{array}{l}0.26^{* * *} \\
(0.00)\end{array}$ \\
\hline \multirow[t]{2}{*}{ H3 } & PEOU $\rightarrow$ Self-expression and productivity (PU1) & $\begin{array}{l}0.14^{* * *} \\
(0.00)\end{array}$ & $\begin{array}{l}0.09 \\
(0.28)\end{array}$ & $\begin{array}{l}0.25^{* * *} \\
(0.00)\end{array}$ & $\begin{array}{l}0.14 \\
(0.38)\end{array}$ & $\begin{array}{l}0.32^{* * *} \\
(0.00)\end{array}$ \\
\hline & PEOU $\rightarrow$ Overall usefulness (PU2) & $\begin{array}{l}0.75^{* * *} \\
(0.00)\end{array}$ & $\begin{array}{l}0.74^{* * *} \\
(0.00)\end{array}$ & $\begin{array}{l}0.66^{* * *} \\
(0.00)\end{array}$ & $\begin{array}{l}0.72^{* * *} \\
(0.00)\end{array}$ & $\begin{array}{l}0.78^{* * *} \\
(0.00)\end{array}$ \\
\hline $\mathrm{H} 4$ & $\mathrm{SN} \rightarrow \mathrm{IU}$ & $\begin{array}{l}0.26^{* * *} \\
(0.00)\end{array}$ & $\begin{array}{l}0.27^{* * *} \\
(0.00)\end{array}$ & $\begin{array}{l}0.26^{* * *} \\
(0.00)\end{array}$ & $\begin{array}{l}0.25^{* *} \\
(0.02)\end{array}$ & $\begin{array}{l}0.17^{* *} \\
(0.04)\end{array}$ \\
\hline \multirow[t]{2}{*}{ H5 } & Leisure and interest (PP1) $\rightarrow I U$ & $\begin{array}{l}0.02 \\
(0.45)\end{array}$ & $\begin{array}{l}0.08 \\
(0.10)\end{array}$ & $\begin{array}{l}-0.05 \\
(0.32)\end{array}$ & $\begin{array}{l}0.14 \\
(0.16)\end{array}$ & $\begin{array}{l}0.05 \\
(0.53)\end{array}$ \\
\hline & Happiness (PP2) $\rightarrow I U$ & $\begin{array}{l}0.15^{* * *} \\
(0.00)\end{array}$ & $\begin{array}{l}0.14^{* *} \\
(0.02)\end{array}$ & $\begin{array}{l}0.15^{* * *} \\
(0.00)\end{array}$ & $\begin{array}{l}0.05 \\
(0.46)\end{array}$ & $\begin{array}{l}0.22^{* * *} \\
(0.00)\end{array}$ \\
\hline \multirow[t]{2}{*}{ H6.a } & $\begin{array}{l}\text { Internet reliability } \rightarrow \text { Self-expression and } \\
\text { productivity (PU1) }\end{array}$ & $\begin{array}{l}0.02 \\
(0.60)\end{array}$ & $\begin{array}{l}0.03 \\
(0.64)\end{array}$ & $\begin{array}{l}-0.12^{*} \\
(0.06)\end{array}$ & $\begin{array}{l}0.15 \\
(0.20)\end{array}$ & $\begin{array}{l}0.20^{* *} \\
(0.02)\end{array}$ \\
\hline & Internet reliability $\rightarrow$ Overall usefulness (PU2) & $\begin{array}{l}0.04 \\
(0.37)\end{array}$ & $\begin{array}{l}0.08 \\
(0.22)\end{array}$ & $\begin{array}{l}0.07 \\
(0.38)\end{array}$ & $\begin{array}{l}0.00 \\
(0.98)\end{array}$ & $\begin{array}{l}-0.05 \\
(0.66)\end{array}$ \\
\hline H6.b & Internet reliability $\rightarrow$ PEOU & $\begin{array}{l}-0.03 \\
(0.35)\end{array}$ & $\begin{array}{l}0.03 \\
(0.61)\end{array}$ & $\begin{array}{l}0.00 \\
(0.97)\end{array}$ & $\begin{array}{l}-0.05 \\
(0.58)\end{array}$ & $\begin{array}{l}-0.08 \\
(0.39)\end{array}$ \\
\hline \multirow[t]{2}{*}{ H6.c } & $\begin{array}{l}\text { Internet speed } \rightarrow \text { Self-expression and } \\
\text { productivity (PU1) }\end{array}$ & $\begin{array}{l}-0.02 \\
(0.70)\end{array}$ & $\begin{array}{l}0.03 \\
(0.64)\end{array}$ & $\begin{array}{l}0.10 \\
(0.18)\end{array}$ & $\begin{array}{l}-0.23^{*} \\
(0.09)\end{array}$ & $\begin{array}{l}-0.29^{* * *} \\
(0.00)\end{array}$ \\
\hline & Internet speed $\rightarrow$ Overall usefulness (PU2) & $\begin{array}{l}-0.04 \\
(0.46)\end{array}$ & $\begin{array}{l}-0.11 \\
(0.13)\end{array}$ & $\begin{array}{l}-0.08 \\
(0.40)\end{array}$ & $\begin{array}{l}-0.06 \\
(0.67)\end{array}$ & $\begin{array}{l}0.25^{*} \\
(0.06)\end{array}$ \\
\hline H6.d & Internet speed $\rightarrow$ PEOU & $\begin{array}{l}-0.02 \\
(0.60)\end{array}$ & $\begin{array}{l}-0.12 \\
(0.78)\end{array}$ & $\begin{array}{l}-0.09 \\
(0.25)\end{array}$ & $\begin{array}{l}0.03 \\
(0.78)\end{array}$ & $\begin{array}{l}0.03 \\
(0.80)\end{array}$ \\
\hline \multirow[t]{5}{*}{$\mathrm{H} 7$} & $\mathrm{IU} \rightarrow \mathrm{AU}$ & $\begin{array}{l}0.32^{* * *} \\
(0.00)\end{array}$ & $\begin{array}{l}0.26^{* *} \\
(0.05)\end{array}$ & $\begin{array}{l}0.64^{* * *} \\
(0.00)\end{array}$ & $\begin{array}{l}0.37 \\
(0.21)\end{array}$ & $\begin{array}{l}0.23 \\
(0.36)\end{array}$ \\
\hline & $n$ & 496 & 189 & 166 & 62 & 79 \\
\hline & Log likelihood & -5681.74 & -2103.76 & -1964.84 & -592.94 & -837.44 \\
\hline & AlC & 11413.49 & 4257.52 & 3979.68 & 1235.88 & 1724.88 \\
\hline & $\mathrm{BIC}$ & 11518.65 & 4338.57 & 4057.48 & 1289.06 & 1784.11 \\
\hline
\end{tabular}

*Significance @ 90\% confidence level **Significance @ 95\% confidence level ***Significance @ 99\% confidence level $p$-value in parenthesis

expression and productivity (PU1) when using these sites. Rather, overall usefulness (PU2) of the sites, perceived ease of use, and opinions of their peers/family determined their intention of use. These differences may be explained by the nature of SNSs being studied. Some authors indicated that not all SNSs have the same function and, thus, determinants affecting its acceptance and usage could vary (Moqbel, 2012; Pillai \& Mukherjee, 2011; Pinho \& Soares, 2011). Since YouTube, the subject of our study, is an entertainment platform, students may find it to be generally useful, but not as a specific tool for work- and/or personal-related goals. This supports the idea of Lee and Lehto (2013) who indicated that 'all individuals may not be equally motivated to recognize YouTube's educational value, since it is conventionally seen as a medium for entertainment, rather than an educational tool' (p. 204). 
Positive associations were found between 'PEOU and IU' and 'SN and IU' and were robust across models. These confirm the known fact that PEOU is a major predictor of intention to use. Although this result differ from some published studies (Alarcón-DelAmo et al., 2012; Ernst et al., 2013; Oum \& Han, 2011), it supports the ideas of Moqbel (2012) who suggested that sytem developers should create less complicated hedonic IS to ensure succesful user acceptance. Furthermore, perceived ease of use is considered to be an important factor in the adoption of technology particularly in non-Western countries (Schepers \& Wetzels, 2007).

Another important finding was that perceived ease of use (PEOU) significantly determines perceived usefulness (PU). This result is consistent with those of other studies and suggest that easy to use and simple social media websites are deemed to be more useful. Hence, social networking sites like YouTube and Facebook should continuously redesign their user interface to increase usability and enhance user experience. YouTube, for instance, recognizes this need, by its continuous work in improving its interface (Long, 2016).

Our results also show that subjective norm (SN) directly affects intention to use (IU), which is consistent with other studies (Choi \& Chung, 2012; Kim et al., 2009; Schepers \& Wetzels, 2007). This indicates that students consider the opinions of people important to them (e.g. family, classmates, friends) when using social media sites. Thus, if faculty members would integrate social media in their classes, students would most likely adopt to this new form of learning.

Earlier, we hypothesized that perceived playfulness (leisure and interest (PP1) and happiness (PP2)) positively influence intention to use. Contrary to expectations, our analyses found that in models 1, 2, 3, and 5, only happiness (PP2) act as an influencer of intention to use while leisure and interest (PP1) is an insignificant factor of intention to use in all models or in either private or public HEIs. It seems possible that these results are due to the idea that students perceive social media as a medium of entertainment and over time they have considered it as part of their daily activities and not just a leisure activity. According to a special report 'Digital in 2016' (Kemp, 2016), Filipinos spend more than $3.5 \mathrm{~h}$ a day on social media, which is the highest among the 30 economies listed. Therefore, engaging in social media-related activities have become a regular habit and students will continue to use it even if it is not during leisure time. This is in agreement with what is published in the website of Pew Research Center (2015) that users in emerging economies are always online and socializing in the Web is their preferred digital activity.

Although it is difficult to compare these results to other studies, it might be related to other published researches that have found out that perceived playfulness does not affect intention to use (Padilla-Meléndez et al., 2013; Suki \& Suki, 2011). Although our study confirms that happiness (PP2) is the only significant construct in terms of perceived playfulness, it is consistent with the results of previous studies that have found out that individuals are using social networking sites because of the delightful experience they received from using it (Ernst et al., 2013; Moqbel, 2012; Oum \& Han, 2011; Sledgianowski \& Kulviwat, 2009).

A comparison between models (private and public HEIs) reveals that there is a difference between the effects of Internet reliability and speed to PU and PEOU. The results in the general model indicate that Internet reliability and speed are not key determinants of both PU and PEOU. Despite the fact that the Philippines has one of the slowest Internet 
connection speed of 3.5 Mbps for the first quarter of 2016 as reported in the "State of Internet" on Asia Pacific (Akamai, 2016), Filipinos still spend an average of $5.2 \mathrm{~h}$ a day surfing the net. Hence, students' perceptions on the usefulness and ease of use of social media would not be affected by the quality of Internet connection. However, in model 5, we found Internet speed to be a significant factor to one's self-expression and productivity as well as to one's overall perceived usefulness of the sites. Reliability of Internet connection was also found to be significant in one public university.

Students in public universities would rely more on school-provided computers and Internet services in the conduct of their Internet-related activities. This may be the case because Internet services at the university are free of charge. The Philippines has one of the most expensive Internet with a monthly average cost of $\$ 18.19$ (P848.65) per Mbps (Shahani, 2015). Likewise, only $26.9 \%$ of households in the Philippines have Internet (The State of Broadband, 2015). In terms of computer ownership, out of the projected 21.5 million Filipino households only 3.8 million households have computers at home for the year 2013 (Labucay, 2014). Thus, students prefer to use the school's resources (might be highly attributed to purchasing power). As more faculty members are using ICT tools in their teachings, students expect that the university would provide them access to computers with superior Internet connection. In contrast, students from private HEIs may have access to Internet through home and/or mobile data subscription, and are, therefore, not solely dependent on the school's network for Internet access.

It is rather interesting that Internet reliability and speed only influence perceived usefulness but not perceived ease of use. We concurred that this may be attributed to the fact that the utility value of a social networking site or any information system would be ineffective because of unstable Internet connection. However, this is contrary to the findings of the study of Al-Somali et al. (2009) on the acceptance of mobile banking that quality of Internet connection significantly affects PEOU.

In the general model, there is evidence that intention to use social media reflects students' actual use. This association are consistent in most general TAM studies (Cheung \& Vogel, 2013; Davis et al., 1989) and in TAM studies applied to social media (Alarcón-Del-Amo et al., 2012; Rauniar et al., 2014; Sledgianowski \& Kulviwat, 2009). However, in public universities, this association does not hold true. This discrepancy could be attributed to lack of resources, for instance, Internet accessibility. As mentioned earlier, most students in public universities do not have access to Internet at home and relies on school network which might not be too reliable. Results point that YouTube may not be the preferred social networking site and that they interact less. There are other substitute sites, such as Facebook, where students can communicate with other members and express their opinions, in varied topics. To better measure actual usage, future studies should investigate the purpose/reasons why users use social networking sites and not just the frequency of usage.

\section{Summary and conclusion}

It is well established in the literature that behavioral intention to use technology, such as social media sites, may explain its actual usage. However, its application to higher education institutions, students' intention to use and actual usage of social media sites are not always the same. We used YouTube as an example of social 
media site and examined students' usage behavior using the Technology Acceptance Model (TAM) and incorporated additional constructs such as subjective norm, perceived playfulness, Internet reliability speed. Using Principal Component Analysis (PCA) and Structural Equation Modeling (SEM), we found that the robust predictors of actual use of these sites were perceived usefulness, perceived ease of use, subjective norm, and perceived playfulness (happiness). However, perceived playfulness (leisure and interest) was not a determinant of intention to use, which indicated that usage of social media has become a daily habit for users. The study results provided educators important insights on what drives students to use social media. For instance, educators who intend to promote social media as a learning tool should ensure that it should be easy and fun for students to share/express their ideas and collaborate with others.

The effects of Internet reliability and speed were significantly different between types of universities. Students from private HEIs were not significantly affected by Internet reliability and speed. This suggest that private universities should initiate or continue the use of social media in classrooms as there is no problem in the access and quality of Internet.

In contrast, public universities should improve the reliability and speed of their Internet connection; wherein there are under investments of ICT infrastructure. Basic ICT services should be given priority, such as subscribing to faster connection and maintaining ICT infrastructure and services (e.g. maintenance of computer laboratories and hiring of IT/computer technicians). Potential collaborations with private businesses and other public institutions as well as building support with their alumni should be explored to boost funds for much-needed infrastructure and services. For example, the Department of Science and Technology, the Philippines' leading agency on science and technology, partners with the academe in the institutionalization of university-based technology business incubators by providing ICT infrastructure and technical assistance.

One interesting feature of understanding behavior of students towards use of social media sites is that it is varied and complex. A natural progression of this work is to compare results to other social media sites, such as Facebook and Wikis, in which many educators are currently using (Moran et al., 2011). Also, further analysis on other constructs should be examined, such as number of devices owned/accessible to the students and the ways social media sites are used in the classroom. HEIs also use social media for other purposes, such as advertising (e.g. creating a Facebook page) (Roblyer, McDaniel, Webb, Herman, \& Witty, 2010), Thus, other users of social media should also be given attention (e.g. alumni and the public).

With these information, educators and university management, have better understanding of their students' behavior and have better planning of their resources to improve the welfare and learning of their students.

Authors' contributions

Both the authors contributed in the planning, conceptualization, implementation, analysis, and writing of this manuscript. They also read and approved the final manuscript. 
degree in management at the University of the Philippines Visayas. She teaches management information systems and use of IT productivity tools.

Cheryl Joy Fernandez is also an Assistant Professor at the College of Management of the University of the Philippines Visayas, where she teaches operations research and business research. Cheryl completed her Bachelor of Science in Economics (cum laude) from the University of the Philippines Visayas. She also has a Postgraduate Diploma in Business Administration and a Master of Management from Massey Business School at Massey University in New Zealand. She completed her PhD at James Cook University in Australia.

\section{Competing interests}

The authors declare that they have no competing interests.

\section{Author details}

${ }^{1}$ Department of Accounting, College of Management University of the Philippines Visayas, Iloilo City, Philippines 5000.

${ }^{2}$ Department of Management, College of Management, University of the Philippines Visayas, lloilo City, Philippines 5000.

\section{Received: 11 August 2016 Accepted: 13 October 2016}

Published online: 01 March 2017

\section{References}

Akamai. (2016). https://www.akamai.com/es/es/multimedia/documents/state-of-theinternet/akamai-state-of-the-internetreport-q1-2016.pdf. Accessed 11 July 2016.

Alarcón-Del-Amo, M.-D.-C., Lorenzo-Romero, C., \& Gómez-Borja, M.-A. (2012). Analysis of acceptance of social networking sites. African Journal of Business Management, 6(29), 8609-8619. doi:10.5897/AJBM11.2664

Al-Somali, S. A., Gholami, R., \& Clegg, B. (2009). An investigation into the acceptance of online banking in Saudi Arabia. Technovation, 29(2), 130-141. doi:10.1016/j.technovation.2008.07.004

Althunibat, A. (2015). Determining the factors influencing students' intention to use $\mathrm{m}$ - learning in Jordan higher education. Computers in Human Beahvior, 52, 65-71.

Arpaci, I. (2016). Understanding and predicting students' intention to use mobile cloud storage services. Computers in Human Behavior, 58, 150-157.

Balakrishnan, V., \& Gan, C. L. (2016). Students' learning styles and their effects on the use of social media technology for learning. Telematics and Informatics, 33(3), 808-821.

Cheung, R., \& Vogel, D. (2013). Predicting user acceptance of collaborative technologies: An extension of the technology acceptance model for e-learning. Computers \& Education, 63, 160-175.

Choi, G., \& Chung, H. (2012). Elaborating the technology acceptance model with social pressure and social benefits for social networking sites (SNSs). Proceedings of the American Society for Information Science and Technology, 49(1), 1-3.

Davis, F. D. (1989). Perceived usefulness, perceived ease of use, and user acceptance of information technology. MIS Quarterly, 319-340.

Davis, F. D., Bagozzi, R. P.. \& Warshaw, P. R. (1989). User acceptance of computer technology: A comparison of two theoretical models. Management Science, 35(8), 982-1003.

Davis Jr, F.D. (1986). A technology acceptance model for empirically testing new end-user information systems: Theory and results (Doctoral dissertation, Massachusetts Institute of Technology).

de Chardin, P. T. (1955). The Formation of the Noosphere, 1947.

De Rivera, J. D. (2016, June 3). Iloilo City ready and able to business globally. BusinessMirror. http://www.businessmirror. com.ph/iloilo-city-ready-and-able-to-do-businessglobally/. Accessed 4 Aug 2016.

Ducey A. J. \& Coovert, M.D. (2016). Predicting tablet computer use: An extended Technology Acceptance Model for physicians. Health Policy and Technology (2016), http://dx.doi.org/10.1016/j.hlpt.2016.03.010.

Ernst, C.P. H., Pfeiffer, J., \& RothLauf, F. (2013). Hedonic and utilitarian motivations of social network site adoption. Johannes Gutenberg University Mainz: Working Papers in Information Systems and Business Administration

Everson, M., Gundlach, E., \& Miller, J. (2013). Social media and the introductory statistics course. Computers in Human Behavior, 29(5), A69-A81.

Fonchamnyo, D. C. (2013). Customers' perception of E-banking adoption in Cameroon: An empirical assessment of an extended TAM. International Journal of Economics and Finance, 5(1), 166-176. doi:10.5539/ijef.v5n1p166

Healy, F. (2015). Technology and the changing education landscape. http://www.leadscon.com/technology-changingeducation-landscape/. Accessed 15 July 2016.

Internet seen as positive influence on education but negative on morality in emerging and developing nations. (2015). Pew Research Center, Washington, D.C. http://www.pewglobal.org/2015/03/19/internet-seen-as-positive-influence-oneducation-but-negative-influence-on-morality-in-emerging-and-developing-nations/. Accessed 30 Jun 2016.

Jolliffe, I. (2002). Principal component analysis. John Wiley \& Sons, Ltd.

Kaplan, A. M., \& Haenlein, M. (2010). Users of the world, unite! The challenges and opportunities of Social Media. Business Horizons, 53(1), 59-68. doi:10.1016/j.bushor.2009.09.003

Kemp, S. (2016). Digital in 2016. http://wearesocial.com/special-reports/digital-in-2016. Accessed 11 July 2016.

Kietzmann, J. H., Hermkens, K., McCarthy, I. P., \& Silvestre, B. S. (2011). Social media? Get serious! Understanding the functional building blocks of social media. Business Horizons, 54(3), 241-251. doi:10.1016/j.bushor.2011.01.005

Kim, H.-B., Kim, T. T., \& Shin, S. W. (2009). Modeling roles of subjective norms and eTrust in customers' acceptance of airline B2C eCommerce websites. Tourism Management, 30(2), 266-277. doi:10.1016/j.tourman.2008.07.001

Labucay, I. D. (2014). Patterns of Internet usage in the Philippines. The Internet and the Google Age: Prospects and Perils, 27

Lane, M., \& Coleman, P. (2012). Technology ease of use through social networking media. Journal of Technology Research, 3, 1-12.

Lee, D. Y., \& Lehto, M. R. (2013). User acceptance of YouTube for procedural learning: An extension of the Technology Acceptance Model. Computers \& Education, 61, 193-208. 
Levinson, P. (2011). The long story about the short medium. Journal of Communication Research, 48, 7-28.

Liao, C.-H., Tsou, C.-W., \& Shu, Y.-C. (2008). The roles of pereived enjoyment and price perception in determining acceptance of multimedia-on-demand. International Journal of Business and Information, 3(1), 27-52.

Long, J. (2016). YouTube is testing a new material UI on the Web. http://www.androidpolice.com/2016/04/30/youtube-istesting-a-new-material-ui-on-the-web/. Accessed 27 July 2016.

Lu, J., Yu, C.-S., Liu, C., \& Yao, J. E. (2003). Technology acceptance model for wireless Internet. Internet Research, 13(3), 206-222. doi:10.1108/10662240310478222

Manca, S., \& Ranieri, M. (2016). "Yes for sharing, no for teaching!": Social Media in academic practices. The Internet and Higher Education, 29, 63-74.

Marangunić, N., \& Granić, A. (2015). Technology acceptance model: A literature review from 1986 to 2013. Universal Access in the Information Society, 14(1), 81-95. doi:10.1007/s10209-014-0348-1

McLoughlin, C. \& Lee, M. J.W. (2008). Future Learning Landscapes: Transforming Pedagogy through Social Software. Innovate: Journal of Online Education, 4(5). http://nsuworks.nova.edu/innovate/vol4/iss5/1/. Accessed on 9 Aug 2016.

Mogbel, M. (2012). Explaining user acceptance of social networking: Employees' perspective. In Proceedings of the Southwest Decision Science Institute Forty Third Annual Conference, February 29-March (Vol. 3, pp. 110-118).

Moran, M., Seaman, J., \& Tinti-Kane, H. (2011). Teaching, learning, and sharing: How today's higher education faculty use social media. Babson Survey Research Group

Orús, C., Barles, M. J., Belanche, D., Casalo, L., Fraj, E., \& Gurrea, R. (2016). The effects of learner-generated videos for YouTube on learning outcomes and satisfaction. Computers \& Education, 95, 254-269.

Oum, S., \& Han, D. (2011). An empirical study of the determinants of the intention to participate in user-created contents (UCC) services. Expert Systems with Applications, 38(12), 15110-15121. doi:10.1016/..eswa.2011.05.098

Padilla-Meléndez, A., Del Aguila-Obra, A. R., \& Garrido-Moreno, A. (2013). Perceived playfulness, gender differences and technology acceptance model in a blended learning scenario. Computers \& Education, 63, 306-317.

Pai, F.-Y., \& Huang, K.-I. (2011). Applying the technology acceptance model to the introduction of healthcare information systems. Technological Forecasting and Social Change, 78(4), 650-660. doi:10.1016/j.techfore.2010.11.007.

Paul, J. A., Baker, H. M., \& Cochran, J. D. (2012). Effect of online social networking on student academic performance. Computers in Human Behavior, 28(6), 2117-2127.

Peters, M. A. \& Heraud, R. (2015). Toward a political theory of social innovation: collective intelligence and the cocreation of social goods. Psychosociological Issues in Human Resource Management, 3(3), 7-24.

Peters, M. A., \& Reveley, J. (2015). Noosphere rising Internet-based collective intelligence, creative labour, and social production. Thesis Eleven, 0725513615575932.

Pikkarainen, T., Pikkarainen, K., Karjaluoto, H., \& Pahnila, S. (2004). Consumer acceptance of online banking: An extension of the technology acceptance model. Internet Research, 14(3), 224-235. doi:10.1108/10662240410542652

Pillai, A., \& Mukherjee, J. (2011). User acceptance of hedonic versus utilitarian social networking web sites. Journal of Indian Business Research, 3(3), 180-191. doi:10.1108/17554191111157047

Pinho, J. C. M. R., \& Soares, A. M. (2011). Examining the technology acceptance model in the adoption of social networks. Journal of Research in Interactive Marketing, 5(2/3), 116-129. doi:10.1108/17505931111187767

Prensky, M. (2001). Digital natives, digital immigrants part 1. On the Horizon, 9(5), 1-6.

Rauniar, R., Rawski, G., Yang, J., \& Johnson, B. (2014). Technology accepatance model (TAM) and social media usage: An empirical study on Facebook. Journal of Enterprise Information Management, 27(1), 6-30. doi:10.1108/JEIM-04-2012-0011

Roblyer, M. D., McDaniel, M., Webb, M., Herman, J., \& Witty, J. V. (2010). Findings on Facebook in higher education: A comparison of college faculty and student uses and perceptions of social networking sites. The Internet and Higher Education, 13(3), 134-140. doi:10.1016/j.iheduc.2010.03.002

Saadé, R., \& Bahli, B. (2005). The impact of cognitive absorption on perceived usefulness and perceived ease of use in on-line learning: An extension of the technology acceptance model. Information \& Management, 42(2), 317-327. doi:10.1016/j.im.2003.12.013

Schepers, J., \& Wetzels, M. (2007). A meta-analysis of the technology acceptance model: Investigating subjective norm and moderation effects. Information and Management, 44(1), 90-103. doi:10.1016/j.im.2006.10.007

Schlenkrich, L., \& Sewry, D. (2012). Factors for successful use of social networking sites in higher education. South African Computer Journal, 49, 12-24.

Selwyn, N. (2012). Social media in higher education. The Europa world of learning, 1-10. Retrieved from http://sites.jmu. edu/flippEDout/files/2013/04/sample-essay-selwyn.pdf

Shahani, L. R. (2015). Why is our Internet so slow? The Philippine Star. http://www.philstar.com/opinion/2015/08/24/ 1491398/why-our-internet-so-slow. Accessed 30 June 2016.

Sledgianowski, D., \& Kulviwat, S. (2009). Using social network sites: The effects of playfulness, critical mass, and trust in a hedonic context. The Journal of Computer Information Systems, 49(4), 74-83.

Sobaih, A. E. E., Moustafa, M. A., Ghandforoush, P., \& Khan, M. (2016). To use or not to use? Social media in higher education in developing countries. Computers in Human Behavior, 58, 296-305.

Suki, N. M., \& Suki, N. M. (2011). Exploring the relationship between perceived usefulness, perceived ease of use, perceived enjoyment, attitude and subscribers' intention towards using $3 \mathrm{G}$ mobile services. Journal of Information Technology Management, 22(1), 1-7.

The State of Broadband 2015: Broadband as a foundation for sustainable development. (2015). http://www. broadbandcommission.org/documents/reports/bb-annualreport2015.pdf. Accessed 20 June 2016.

Turner, M., Kitchenham, B., Brereton, P., Charters, S., \& Budgen, D. (2010). Does the technology acceptance model predict actual use? A systematic literature review. Information and Software Technology, 52(5), 463-479. doi:10.1016/j.infsof.2009.11.005

Venkatesh, V., \& Davis, F. D. (2000). A theoretical extension of the technology acceptance model: Four longitudinal field studies. Management Science, 46(2), 186-204. 